\title{
Pengaruh Kualitas Pelayanan Dan Fasilitas Terhadap Loyalitas Melalui Kepuasan Konsumen Pada Café Hangout Di Sampit
}

\author{
Yesi Triyuliarlita Amelia ${ }^{1}$, Koko Safitri ${ }^{2}$ \\ Sekolah Tinggi Ilmu Ekonomi Sampit ${ }^{1,2}$ \\ Yesi.TA@gmail.com \\ Kokosafitri@gmail.com
}

\begin{abstract}
Abstrak
Tujuan penelitian ini adalah untukk mengetahui pengaruh kualitas Pelayanan dan Fasilitas terhadap Loyalitas di café Hangout Sampit melalui kepuasan konsumen sebagai variabel intervening. Dengan teknik pengambilan sampel menggunakan teknik nonprobability sampling dimana pengambilan sampel yang tidak memberi peluang atau kesempatan yang sama bagi setiap unsur atau anggota populasi untuk dipilih menjadi sampel. Hasil Uji Hipotesis dalam penelitian ini untuk variabel Kualitas pelayanan (X1) terhadap variabel Loyalitas (Y) dengan path Coefficients bernilai positif 0,91 dengan nilai $P$ values $<0,001$ lebih kecil dari 0,05 dan $R$ - Square bernilai 0,84 itu berarti Kualitas pelayanan berpengaruh positif terhadap loyalitas dengan besar pengaruhnya sebesar $84 \%$. Hasil Uji hipotesis untuk variabel Fasilitas (X2) terhadap Loyalitas (Y) dengan Nilai Path Coefficients bernilai positif 0,90 dengan nilai $p$ values $<0,001$ lebih kecil dari 0,05 dan $R$-Square bernilai 0,82 itu berarti Fasilitas berpengaruh positif terhadap loyalitas dengan besar pengaruhnya sebesar 82\%. Hasil Uji hipotesis untuk variabel Kualitas Produk (X1) terhadap Kepuasan Konsumen $(\mathrm{Z})$ dengan Nilai Path Coefficients bernilai positif 0,94 dengan nilai $p$ values $<0,001$ lebih kecil dari 0,05 dan $R$-Square bernilai 0,89 itu berarti Kualitas pelayanan berpengaruh positif terhadap kepuasan konsumen dengan besar pengaruhnya sebesar $89 \%$. \%. Hasil Uji hipotesis untuk variabel Fasilitas (X2) terhadap Kepuasan konsumen (Z) dengan Nilai Path Coefficients bernilai positif 0,94 dengan nilai $p$ values $<0,001$ lebih kecil dari 0,05 dan $R$-Square bernilai 0,89 itu berarti Fasilitas berpengaruh positif terhadap Kepuasan konsumen dengan besar pengaruhnya sebesar 89\%. Hasil Uji hipotesis untuk variabel Kepuasan Konsumen (Z) terhadap Loyalitas (Y) dengan Nilai Path Coefficients bernilai positif 0,95 dengan nilai $p$ values $<0,001$ lebih kecil dari 0,05 dan $R$-Square bernilai 0,91 itu berarti Kepuasan Konsumen berpengaruh positif terhadap Loyalitas dengan besar pengaruhnya sebesar $91 \%$.
\end{abstract}

Kata Kunci: Kualitas pelayanan, Fasilitas, Kepuasan, Loyalitas.

\begin{abstract}
The purpose of this study was to determine the effect of service quality and facilities influence on loyalty in the cafe. Hangout Sampit consumer satisfaction as an intervention variable. By taking the sample using nonprobability sampling technique where sampling does not provide equal opportunities or opportunities for each element or member of the population to be selected as samples. The results of the Hypothesis Test in this study for the variable service quality $(X 1)$ to the Loyalty variable $(Y)$ with the coefficient path is positive 0.91 with a $P$ value $<0.001$ less than 0.05 and $R$-Square is 0.84 which means Quality service has a positive effect on loyalty with a large influence of $84 \%$. Hypothesis test results for the Facility variable (X2) on Loyalty $(Y)$ with a positive Path Coefficients value of 0.90 with a $p$ value $<0.001$ less than 0.05 and $R$-Square of 0.82 means that facilities have a positive effect on loyalty. with a large influence of $82 \%$. Hypothesis test results for the variable Product Quality (X1) on Customer Satisfaction (Z) with the value of Path Coefficients having a positive value of 0.94 with a $p$ value $<0.001$ less than 0.05 and $R$-Square having a value of 0.89 which means that service quality has an effect positive on consumer satisfaction with a large effect of $89 \%$. \%. Hypothesis test results for the Facility variable (X2) on customer satisfaction (Z) with a positive path coefficients value of 0.94 with a $p$ value $<0.001$ less than 0.05 and $R$-Square value of 0.89, it means that facilities have a positive effect on Consumer satisfaction with the influence of $89 \%$. Hypothesis test results for the variable Customer Satisfaction $(Z)$ on Loyalty $(Y)$ with the value of Path Coefficients having a positive value of 0.95 with a $p$ value $<0.001$ less than 0.05 and $R$-Square having a value of 0.91 which means that customer satisfaction has a positive effect to Loyalty with a big influence of $91 \%$.
\end{abstract}

Keywords: Quality of service, facilities, satisfaction, loyalty. 


\section{PENDAHULUAN}

Perkembangan bisnis cafe di Indonesia saat ini sedang berkembang sangat pesat. Hal ini dapat dilihat Banyaknya cafe yang bermunculan terutama di Sampit dikarenakan cafe sudah menjadi gaya hidup bagi kebanyakan orang di jaman sekarang, dengan menyediakan tempat dengan desain interior yang menarik serta menawarkan suasana yang nyaman dan menyenangkan. Serta menyediakan berbagai macam konsep sehingga menarik minat beli konsumen. Selain untuk bersantai café baru-baru ini digunakan sebagai tempat untuk berkumpul dengan keluarga, teman, sahabat bahkan rekan bisnis. Café sebagai tempat pilihan pada masyarakat generasi millennials sekarang ini, desain interior café pada umumnya membuat suasana nyaman untuk berkumpul dan bersantai, selain tempatnya yang nyaman sebuah café juga menyediakan berbagai macam menu yang beragam seperti halnya minuman kopi yang bermacam-macam sampai dengan cemilan dan makanan yang sangat bervariasi. Untuk para pecinta kopi café sebagai surga bagi mereka, kopi yang beragam variasinya menjadi daya Tarik untuk mereka, yang terpenting kenikmatan yang di dapat dari kopi yang diracik dengan sempurna dan sesuai takaran yang pas akan menjadi daya Tarik tersendiri bagi para pecinta kopi, seperti halnya Café Hangout yang berada di Jalan Pelita Timur yang nyediakan berbagai macam varian kopi.

Café Hangout merupakan salah satu café yang berada di kota Sampit yang memiliki desain interior klasik modern, selain itu café hangout memilik dua lantai pada café tersebut, dicafe ini juga menyediakan berbagai menu makan yang bervariasi, selain menu makanan ada juga menu minuman yang berbahan dasar buah-buahan dan juga variasi susu. Serta yang terpenting ada banyak variasi minuman yang berbahan dasar kopi seperti halnya kopi capuchino, V60, vanillalate, hazelnutlatte, vietnamdrip, americano dan lain sebagainya.

Dengan bertambahnya jumlah café yang ada di Sampit dan kompleksitas dalam kehidupan masyarakat yang semakin meningkat, menyebabkan kebutuhan untuk bisnis café semakin meningkat. Hal ini direspon oleh para pelaku bisnis café untuk berusaha memenuhi kebutuhan tersebut, dengan menambah prasarana maupun memberikan pelayanan yang lebih baik lagi. Setiap Café berusaha memberikan pelayanan yang terbaik dengan fasilitas yang memenuhi harapan konsumennya agar mereka menjadi pelanggan setia terhadap café tersebut.
Sehingga konsumen tidak ragu lagi untuk mengunjungi Café Hangout tersebut. Kualitas pelayanan menjadi faktor utama yang mempengaruhi loyalitas pelanggan dikarenakan apa bila pelanggan mendapatkan pelayanan yang diinginkan akan mengalami mood yang positif terhadap pelayanan tersebut sehingga memiliki loyalitas yang tinggi terhadap perusahaan tersebut (Starini, 2013).

Faktor yang tidak kalah penting dari kualitas pelayanan adalah mengenai fasilitas. fasilitas dalam usaha harus di perhatikan terutama yang berkaitan dan berhubugan dengan apa yang dirasakan oleh konsumen karena dalam usaha sebuah café, konsumen cenderung menilai suatu perusahaan berdasarkan atas apa yang diperoleh mereka dari perusahaan tersebut. persepsi yang diperoleh dari interaksi pelanggan dengan fasilitas berpengaruh terhadap perusahaan dimata pelanggan (Tjiptono, 2016).

\section{TINJAUAN PUSTAKA}

\section{Kualitas Pelayanan}

Kualitas merupakan salah satu kunci dalam memenangkan persaingan dengan pasar. Ketika perusahaan telah mampu menyediakan produk berkualitas maka telah membangun salah satu fondasi untuk menciptakan kepuasan pelanggan. Menurut Tjiptono (2016) menyatakan bahwa kualitas sebagai kondisi dinamis yang berhubungan dengan produk, jasa, sumber daya manusia, proses, dan lingkungan yang memenuhi atau melebihi harapan. Perkembangan perusahaan menciptakan persaingan yang ketat. Berbagai cara dilakukan agar dapat memperoleh pelanggan dan mempertahankannya. Salah satu strategi yang dipakai perusahaan untuk bisa memenangkan persaingan adalah dengan kualitas layanan yang baik. Pelanggan tertarik membeli sebuah produk atau jasa karena kualitas layanan yang baik. Menurut Tjiptono dan Chandra (2016) mendefinisikan kualitas jasa sebagai ukuran seberapa bagus tingkat layanan yang diberikan mampu sesuai dengan ekspektasi pelanggan. Berdasarkan definisi ini, kualitas jasa bisa diwujudkan melalui pemenuhan kebutuhan dan keinginan pelanggan serta ketepatan penyampaiannya untuk mengimbangi harapan pelanggan. Ada 2 faktor utama yang mempengaruhi Kualitas Jasa menurut Tjiptono \& Chandra (2016), jasa yang diharapkan (Expected Service) dan jasa yang dirasakan/ dipersepsikan (Perceived Service). Menurut Tjiptono dan Chandra (2016) mengidentifikasikan 5 Gap (Kesenjangan) Kualitas 
Pelayanan Jasa yang diperlukan dalam pelayanan jasa, kelima gap tersebut adalah:

1. Kesenjangan antara Harapan Pelanggan dan Persepsi Manajemen (Knowledge Gap)

2. Kesenjangan antara Persepsi Manajemen terhadap Harapan Pelanggan dan Spesifikasi Kualitas Jasa (Standard Gap)

3. Kesenjangan Spesifikasi kualitas Jasa dan penyampaian Jasa (Delivery Gap)

4. Kesenjangan antara Penyampaian Jasa dan Komunikasi Eksternal (Communication Gap)

5. Kesenjangan antara Jasa yang dipersepsikan dan Jasa yang di Harapkan (Service Gap)

Menurut Kotler dalam Tjiptono (2016) mengungkapkan ada terdapat lima faktor dominan atau penentu kualitas pelayanan jasa, kelima faktor dominan tersebut diantarnya yaitu:

1. Berwujud (Tangible), yaitu berupa penampilan fisik, peralatan dan berbagai materi komunikasi yang baik.

2. Empati (Empathy), yaitu kesediaan karyawan dan pengusaha untuk lebih peduli memberikan perhatian secara pribadi kepada pelanggan. Misalnya karyawan harus mencoba menempatkan diri sebagai pelanggan. Jika pelanggan mengeluh maka harus dicari solusi segera, agar selalu terjaga hubungan harmonis, dengan menunjukan rasa peduli yang tulus. Dengan cara perhatian yang diberikan para pegawai dalam melayani dan memberikan tanggapan atas keluhan para konsumen.

3. Cepat tanggap (Responsiveness), yaitu kemauan dari karyawan dan pengusaha untuk membantu pelanggan dan memberikan jasa dengan cepat serta mendengar dan mengatasi keluhan konsumen. Dengan cara keinginan para pegawai dalam membantu dan memberikan pelayanan dengan tanggap, kemampuan memberikan pelayanan dengan cepat dan benar, kesigapan para pegawai untuk ramah pada setiap konsumen, kesigapan para pegawai untuk bekerja sama dengan konsumen.

4. Keandalan (Reliability), yaitu kemampuan untuk memberikan jasa sesuai dengan yang dijanjikan, terpercaya dan akurat, serta konsisten. Contoh dalam hal ini antara lain, kemampuan karyawan dalam memberikan pelayanan yang terbaik, kemampuan karyawan dalam menangani kebutuhan konsumen dengan cepat dan benar, kemampuan perusahaan dalam memberikan pelayanan yang baik sesuai dengan harapan konsumen.

5. Kepastian (Assurance), yaitu berupa kemampuan karyawan untuk menimbulkan keyakinan dan kepercayaan terhadap janji yang telah dikemukakan kepada konsumen. Contoh dalam hal ini antara lain, pengetahuan dan keterampilan pegawai dalam menjalankan tugasnya, pegawai dapat diandalkan, pegawai dapat memberikan kepercayaan kepada konsumen, pegawai memiliki keahlian teknis yang baik.

\section{Fasilitas}

Sebelum melakukan pembelian suatu barang atau jasa konsumen akan dihadapkan pada suatu masalah pokok yaitu mengenai barang atau jasa apa yang akan dibeli dimana melibatkan individu dalam menilai, mendapatkan dan mempergunakan barang-barang dan jasa ekonomis. Menurut Tjiptono (2016) fasilitas merupakan sumber daya fisik yang harus ada sebelum suatu jasa ditawarkan kepada konsumen, sedangkan menurut Nirwana (2004) fasilitas merupakan bagian dari variabel pemasaran jasa yang memiliki peranan cukup penting, karena jasa yang disampaikan kepada pelanggan tidak jarang sangat memerlukan fasilitas pendukung dalam penyampaiannya. Fasilitas merupakan sesuatu yang penting dalam usaha jasa, oleh karena itu fasilitas yang ada yaitu kondisi fasilitas, desain interior dan eksterior serta kebersihan harus dipertimbangkan terutama yang berkaitan erat dengan apa yang dirasakan konsumen secara langsung. Persepsi yang diperoleh dari interaksi pelanggan dengan fasilitas jasa berpengaruh terhadap kualitas jasa tersebut dimata pelanggan. Menurut Mudie dan Cottam dalam Tjiptono (2016) unsurunsur yang perlu dipertimbangkan dalam menentukan fasilitas adalah:

\section{Pertimbangan / Perencanaan}

Spasial Aspek-aspek seperti simetri, proporsi, tekstur, warna, dan lain-lain dipertimbangkan, dikombinasikan, dan dikembangkan untuk memancing respon intelektual maupun emosional dari pemakai orang atau yang melihatnya

2. Perencanaan Ruangan

Unsur ini mencakup perancangan inteior dan arsitektur, seperti penempatan perabotan dan perlengkapannya dalam ruangan, desain aliran sirkulasi dan lain-lain.

3. Perlengkapan / Perabotan 
Perlengkapan memiliki berbagai fungsi, diantaranya sebagai sarana pelindung barangbarang berharga berukuran kecil, sebagai barang pajangan, sebagai tanda penyambutan bagi para pelanggan, dan sebagai sesuatu yang menunjukkan status pemilik atau penggunanya.

\section{Tata Cahaya}

Beberapa yang perlu diperhatikan dalam mendesain tata cahaya adalah warna, jenis, dan sifat aktivitas yang dilakukan di dalam ruangan, dan suasana yang diinginkan.

5. Warna

Warna dapat menggerakkan perasaan dan emosi Warna dapat dimanfaatkan untuk meningkatkan efisiensi dalam ruangan, menimbulkan kesan rileks, mengurangi kecelakaan

6. Pesan-pesan yang disampaikan secara grafis

Aspek penting dan saling terkait dalam unsur ini adalah penampilan visual, penempatan, pemilihan bentuk fisik, pemilihan warna, dan pemilihan bentuk perwajahan lambang atau tanda untuk maksud tertentu.

\section{Kepuasan Konsumen}

Pengertian Kepuasan Konsumen Menurut Kotler (2016) kepuasan konsumen adalah hasil yang dirasakan oleh pembeli yang mengalami kinerja sebuah perusahaan yang sesuai dengan harapannya. Pelanggan merasa puas kalau harapan mereka terpenuhi, dan merasa amat gembira kalau harapan mereka terlampaui. Pelanggan yang puas cenderung tetap loyal lebih lama, membeli lebih banyak, kurang peka terhadap perubahan harga dan pembicaraannya menguntungkan perusahaan. Tjiptono (2016) "mengupkapkan bahwa kepuasan pelanggan adalah situasi kognitif pembeli berkenaan dengan kesepadanan atau ketidaksepadanan antara hasil yang didapatkan dibandingkan dengan pengorbanan yang dilakukan". Setelah mengkonsumsi suatu produk atau jasa, konsumen akan memiliki perasaan puas atau tidak puas terhadap produk atau jasa yang dikonsumsinya. Kepuasan akan mendorong konsumen membeli dan mengonsumsi ulang produk tersebut. Sebaliknya, perasaan yang tidak puas akan menyebabkan konsumen kecewa dan menghentikan pembelian kembali. Pentingnya pengukuran kepuasan konsumen adalah melakukan yang tebaik aspek-aspek yang terpenting bagi pelanggan, Hasan (2014) menjelaskan metode yang dapat digunakan utuk mengukur kepuasan pelanggan, dapat dijelaskan sebagai berikut:

1. Konfirmasi harapan, yaitu dalam konsep ini, kepuasan tidak diukur langsung, namun disimpulkan dalam kesesuaiam atau ketidak sesuaian antara harapan pelanggan dan kinerja aktual produk perusahaan.

2. Minat pembelian ulang, yaitu kepuasan pelanggan diukur secara behavioral dengan menanyakan apakah pelanggan akan berbelanja atau menggunakan jasa perusahaan lagi.

3. Kesediaan untuk merekomendasi, yaitu dalam kasus produk yang pembelian ulangnya relatif lama (seperti pembelian produk, dan sewa tempat dan sebagainya), kesediaan pelanggan untuk merekomendasikan kepada teman atau keluarganya menjadi ukuran yang penting untuk dianalisis dan ditinjak lanjuti.

4. Ketidak kepuasan konsumen, yaitu aspek-aspek yang ditelaah guna mengetahui ketidakpuasan pelanggan adalah (a) komplain, (b) pengembalian produk, (c) word of mouth negatif (rekomendasi negatif).

\section{Loyalitas}

Sebagaimana diketahui bahwa tujuan dari suatu bisnis adalah untuk menciptakan para pelanggan merasa puas. Terciptanya kepuasaan dapat memberikan beberapa manfaat, diantaranya hubungan antara perusahaan dengan pelanggannya menjadi harmonis sehingga memberikan dasar yang baik bagi pembelian ulang dan terciptanya kesetiaan terhadap merek serta membuat suatu rekomendasi dari mulut ke mulut (word of mouth) yang menguntungkan bagi perusahaa. Loyalitas konsumen adalah komitmen pelanggan terhadap suatu merek, toko atau pemasok berdasarkan sifat yang sangat positif dalam pembelian jangka panjang (Tjiptono (2016). Dari pengertian ini dapat diartikan bahwa kesetiaan terhadap merek diperoleh karena adanya kombinasi dari kepuasan dan keluhan. Sedangkan kepuasan pelanggan tersebut hadir dari seberapa besar kinerja perusahaan untuk menimbulkan kepuasan tersebut dengan meminimalkan keluhan sehingga diperoleh pembelian jangka panjang yang dilakukan oleh konsumen.

Loyalitas pelanggan sangat penting artinya bagi perusahaan yang menjaga kelangsungan usahanya maupun kelangsungan kegiatan usahanya. Pelanggan 
yang setia adalah mereka yang sangat puas dengan produk dan pelayanan tertentu, sehingga mempunyai antusiasme untuk memperkenalkannya kepada siapapun yang mereka kenal. Selanjutnya pada tahap berikutnya pelanggan yang loyal tersebut akan memperluas "kesetiaan" mereka pada produk-produk lain buatan produsen yang sama. Dan pada akhirnya mereka adalah konsumen yang setia pada produsen atau perusahaan tertentu untuk selamanya. Kotler (2016) menyatakan bahwa loyalitas tinggi adalah pelanggan yang melakukan pembelian dengan prosentasi makin meningkat pada perusahaan tertentu daripada perusahaan lain.

Dalam upaya untuk mempertahankan pelanggan harus mendapatkan prioritas yang lebih besar dibandingkan untuk mendapatkan pelanggan baru. Oleh karena itu, loyalitas pelanggan berdasarkan kepuasan murni dan terus-menerus merupakan salah satu aset terbesar yang mungkin didapat oleh perusahaan.

\section{METODOLOGI PENELITIAN}

\section{Hipotesis}

Berdasarkan pada latar belakang, rumusan masalah, tujuan penelitian dan landasan teori. Maka hipotesis yang diajukan pada penelitian ini adalah:

$\mathrm{H}_{1}$ : Kualitas pelayanan berpengaruh signifikan terhadap loyalitas konsumen pada Café Hangout di Sampit

H2 : Fasilitas berpengaruh signifikan terhadap loyalitas konsumen pada Café Hangout di Sampit

H3 : Kualitas pelayanan berpengaruh signifikan terhadap kepuasan konsumen pada Café Hangout di Sampit

H4 : Fasilitas berpengaruh signifikan terhadap kepuasan konsumen pada Café Hangout di Sampit

H5 : Kepuasan Konsumen berpengaruh signifikan Terhadap Loyalitas pada Café Hangout di Sampit

\section{Populasi dan Sampel}

Populasi dapat diartikan sebagai wilayah generalisasi yang terdiri dari obyek atau subyek yang mempunyai kualitas dan karakteristik tertentu yang ditetapkan oleh peneliti untuk dipelajari dan kemudian ditarik kesimpulannya (Sugiyono, 2012). Populasi dalam penelitian ini adalah Masyarakat Sampit yang berkunjung ke Café Hangout di Sampit.
Sampel adalah sebagian dari jumlah dan karakteristik yang dimiliki oleh populasi, Sugiyono (2012). Teknik pengambilan sampel dalam penelitian ini adalah nonprobability sampling, yaitu teknik pengambilan sampel yang tidak memberi peluang atau kesempatan yang sama bagi setiap unsur atau anggota populasi untuk dipilih menjadi sampel. Jenis nonprobability sampling yang digunakan adalah purposive sampling dengan menggunakan karakteristik berjenis kelamin lakilaki atau perempuan dengan usia minimal 15 tahun dan pernah berkunjung ke Café Hangout di Sampit minimal dalam rentang waktu 1 bulan terakhir

Penentuan jumlah sampel dalam penelitian ini menggunakan pendekatan Cohen dalam Sholihin (2013). Dalam model penelitian ini jumlah anak panah terbesar yang mengenai satu konstruk sebanyak 3 dengan tingkat signifikan $1 \%$ dan $\mathrm{R}^{2}$ minimun sebesar 0,5 maka ukuran sampel minimum 53.

\section{Definisi Operasional Variabel Penelitian}

Untuk memberi batasan pengukuran agar tidak terjadi kesalahan dalam hal menafsirkan, variabel yang dianalisis perlu didefinisikan. Definisi operasional yang akan dianalisis sebagai berikut:

\section{Variabel Eksogen (Variabel X)}

Variabel ini sering disebut sebagai variabel stimulus, prediktor, antecendent. Dalam bahasa Indonesia sering disebut sebagai variabel bebas/terikat. Variabel bebas merupakan variabel yang mempengaruhi atau yang menjadi sebab perubahannya atau timbulnya variabel dependen/terikat (Sugiyono, 2012). Sedangkan dalam path analysis, variabel bebas disebut sebagai variabel eksogen. Dalam penelitian ini yang menjadi variabel eksogen adalah sebagai berikut:

1. Kualitas pelayanan $\left(\mathrm{X}_{1}\right)$

Menurut Tjiptono (2016) menyatakan bahwa Kualitas pelayanan adalah tingkat keunggulan yang diharapkan dan pengendalian atas tingkat keunggulan tersebut untuk memenuhi keinginan pelanggan. Variabel Kualitas pelayanan dianalisis dengan indikator-indikator berwujud (tangible); empati (empathy); cepat tanggap (responsiveness); keandalan (reliability); dan kepastian (assurance)

2. Fasilitas $\left(\mathrm{X}_{2}\right)$

Menurut Tjiptono (2016) fasilitas merupakan sumber daya fisik yang harus ada sebelum suatu jasa ditawarkan kepada konsumen. oleh karena itu fasilitas yang ada yaitu kondisi fasilitas, desain interior dan eksterior serta kebersihan harus dipertimbangkan terutama yang berkaitan erat dengan apa yang dirasakan 
konsumen secara langsung. Persepsi yang diperoleh dari interaksi pelanggan dengan fasilitas jasa berpengaruh terhadap kualitas jasa tersebut dimata pelanggan yaitu 1) Perencanaan; 2) Perencanaan ruangan; 3) Perlengkapan/perabotan; 4) Tata cahaya; 5) Warna; dan 6) Pesan-pesan

\section{Variabel Intervening (Variabel Z)}

Variabel intervening adalah variabel yang secara teoritis mempengaruhi hubungan antara variabel independen (bebas) dengan dependen (terikat), tetapi tidak dapat diamati dan diukur. Variabel ini merupakan variabel penyela (antara) yang terletak di antara variabel eksogen dan endogen, sehingga variabel eksogen tidak langsung mempengaruhi berubahnya atau timbulnya variabel endogen (Sugiyono, 2012). Variabel intervening (Z) dalam penelitian ini adalah Kepuasan Konsumen Menurut (Kotler, 2012) kepuasan konsumen adalah hasil yang dirasakan oleh pembeli yang mengalami kinerja sebuah perusahaan yang sesuai dengan harapannya. Pelanggan merasa puas kalau harapan mereka terpenuhi, dan merasa amat gembira kalau harapan mereka terlampaui. Indikator yang digunakan untuk mengukur kepuasan pelanggan meliputi kualitas produk, kualitas pelayanan, faktor emosional, harga produk dan biaya

\section{Variabel Endogen (Variabel Y)}

Variabel ini sering disebut sebagai variabel output, kriteria, konsekuen, dalam bahasa Indonesia sering disebut sebagai variabel terikat/tergantung. Variabel terikat merupakan variabel yang dipengaruhi atau menjadi akibat, karena adanya variabel bebas (Sugiyono, 2012). Sedangkan dalam path analysis variabel terikat disebut sebagai variabel endogen. Variabel endogen (Y) dalam penelitian ini Menurut Tjiptono (2016) loyalitas konsumen adalah komitmen pelanggan terhadap suatu merek, toko atau pemasok berdasarkan sifat yang sangat positif dalam pembelian jangka panjang. Dari pengertian ini dapat diartikan bahwa kesetiaan terhadap merek diperoleh karena adanya kombinasi dari kepuasan dan keluhan indikator yang digunakan untuk mengukur loyalitas pelanggan adalah 1) Melakukan pembelian ulang secara teratur (makes regular purchases); 2) Melakukan pembelian diluar lini produk/jasa (purchases across and services); 3) Merekomendasikan produk (Refers other); dan 4) Menunjukan kekebalan dari daya tarikan produk sejenis dari pesaing.

\section{HASIL DAN PEMBAHASAN}

\section{Hasil Uji Validitas}

Prosedur pengujian validitas adalah convergent validity yaitu dengan mengkorelasikan skor item (component score) dengan construct score yang kemudian menghasilkan nilai loading factor. Dikatakan tinggi jika komponen atau loading factor lebih dari 0,70 dengan nilai $\mathrm{P}$ Value $<0,05$ (Hair, 2013). Dalam penelitian ini, kevalidan atau tidaknya dilihat dari hasil output program WarpPLS dengan versi 3.0. Adapun uji validitas dalam penelitian ini diambil sebanyak 53 Responden, dengan hasil yang akan diuraikan sebagai berikut:

1. Uji Validitas untuk item-item pertanyaan pada variabel Kualitas Pelayanan (X1) yang diambil sebanyak 53 Responden, dengan hasil sebagai berikut:

Tabel 1 Hasil Uji Validitas Variabel Kualitas Produk (X1)

\begin{tabular}{cccc}
\hline $\begin{array}{c}\text { Kualitas } \\
\text { Pelayanan }\end{array}$ & $\begin{array}{c}\text { Loading } \\
\text { factor }\end{array}$ & P value & Status \\
\hline X1.1 & 0,734 & 0,001 & valid \\
X1.2 & 0,853 & 0,001 & valid \\
X1.3 & 0,789 & 0,001 & valid \\
X1.4 & 0,794 & 0,001 & Valid \\
X1.5 & 0,894 & 0,001 & Valid \\
\hline
\end{tabular}

Sumber: Data diolah, 2020

Berdasarkan Tabel di atas perhitungan hasil Uji Validitas dari 53 responden menunjukan bahwa seluruh total item pertanyaan memiliki loading factor lebih besar dari 0,70 dan $P$ value di bawah 0,05 dalam ini maka dapat dikatakan bahwa pertanyaan diatas dianggap Valid (Hair, 2013).

2. Uji Validitas untuk item-item pertanyaan pada variabel Fasilitas (X2) yang diambil sebanyak 53 Responden, dengan hasil sebagai berikut:

Tabel 2 Hasil Uji Validitas Variabel Fasilitas (X2)

\begin{tabular}{lccc}
\hline Fasilitas & $\begin{array}{c}\text { Loading } \\
\text { factor }\end{array}$ & P value & Status \\
X2.1 & 0,744 & 0,001 & valid \\
X2.2 & 0,774 & 0,001 & valid \\
X2.4 & 0,759 & 0,001 & valid \\
X2.5 & 0,910 & 0,001 & valid \\
X2.6 & 0,848 & 0,001 & valid \\
X2.7 & 0,900 & 0,001 & valid \\
\hline
\end{tabular}

Sumber: Data diolah, 2020 
Berdasarkan Tabel di atas perhitungan hasil Uji Validitas dari 53 responden menunjukan bahwa seluruh total item pertanyaan memiliki loading factor lebih besar dari 0,70 dan $P$ value di bawah 0,05 dalam ini maka dapat dikatakan bahwa pertanyaan diatas dianggap Valid (Hair, 2013).

3. Adapun hasil dari Uji Validitas untuk itemitem pertanyaan pada variabel Kepuasan Konsumen (Z) yang diambil sebanyak 53 Responden, dengan hasil sebagai berikut:

Tabel 3 Hasil Uji Validitas Variabel Kepuasan konsumen $(Z)$

\begin{tabular}{cccc}
\hline $\begin{array}{c}\text { Kepuasan } \\
\text { Konsumen }\end{array}$ & $\begin{array}{c}\text { Loading } \\
\text { factor }\end{array}$ & P value & Status \\
\hline Z1 & 0,882 & 0,001 & valid \\
Z2 & 0,865 & 0,001 & valid \\
Z3 & 0,791 & 0,001 & valid \\
Z4 & 0,811 & 0,001 & valid \\
Z5 & 0,731 & 0,001 & valid \\
\hline
\end{tabular}

Sumber: Data diolah, 2020

Berdasarkan Tabel di atas perhitungan hasil Uji Validitas dari 53 Responden. Menunjukan bahwa seluruh total item pertanyaan memiliki loading factor lebih besar dari 0,70 dan $P$ value di bawah 0,05 dalam ini maka dapat dikatakan bahwa pertanyaan diatas dianggap Valid (Hair, 2013).

4. Adapun hasil dari Uji Validitas untuk itemitem pertanyaan pada variabel Loyalitas (Y) yang diambil sebanyak 53 Responden, dengan hasil sebagai berikut:

Tabel 4 Hasil Uji Validitas Variabel Loyalitas (Y)

\begin{tabular}{cccc}
\hline Loyalitas & $\begin{array}{c}\text { Loading } \\
\text { factor }\end{array}$ & P value & Status \\
\hline Y1 & 0,820 & 0,001 & valid \\
Y2 & 0,797 & 0,001 & valid \\
Y3 & 0,849 & 0,001 & valid \\
Y4 & 0,849 & 0,001 & valid \\
\hline
\end{tabular}

Berdasarkan Tabel di atas perhitungan hasil Uji Validitas dari 53 responden menunjukan bahwa seluruh total item pertanyaan memiliki loading factor lebih besar dari 0,70 dan $P$ value di bawah 0,05 dalam ini maka dapat dikatakan bahwa pertanyaan diatas dianggap Valid (Hair, 2013).

\section{Uji Reliabilitas Penelitian}

Realibilitas menyatakan sejauh mana hasil atau pengukuran dapat dipercaya atau dapat diandalkan serta memberikan hasil pengukuran yang relatif konsisten setelah dilakukan beberapa kali pengukuran. Untuk mengukur tingkat reliabilitas variabel penelitian, maka digunakan koefisien alpha atau Cronbachs alpha dan composite reliability. Item pengukuran dikatakan reliable jika memiliki nilai koefisien alpha lebih besar dari 0.7 (Ghozali, 2014). Dalam penelitian ini, Reliable atau tidaknya dilihat dari hasil output program WarpPLS dengan versi 3.0. Adapun uji reliabilitas dalam penelitian ini diambil sebanyak 53 Responden, dengan hasil yang akan diuraikan sebagai berikut:

Tabel 5 Hasil Uji Reliabilitas Variabel X1, X2, Z, dan Y

\begin{tabular}{lccc}
\hline \multicolumn{1}{c}{ Variabel } & $\begin{array}{c}\text { Cronbachs } \\
\text { alpha }\end{array}$ & $\begin{array}{c}\text { Composite } \\
\text { reliability }\end{array}$ & Keterangan \\
\hline $\begin{array}{l}\text { Kualitas } \\
\text { Pelayanan }\end{array}$ & 0,872 & 0,908 & Reliabel \\
$\begin{array}{l}\text { Fasilitas } \\
\text { Kepuasan }\end{array}$ & 0,904 & 0,927 & Reliabel \\
$\begin{array}{l}\text { Konsumen } \\
\text { Loyalitas }\end{array}$ & 0,875 & 0,910 & Reliabel \\
\hline Sumber: Data diolah, 2020 & 0,847 & 0,897 & Reliabel \\
\hline
\end{tabular}

Berdasarkan Perhitungan hasil Uji Reliabilitas instrumen penelitian di atas menunjukkan bahwa Keempat variabel yaitu Kualitas Pelayanan (X1), Fasilitas (X2), Kepuasan Konsumen (Z) dan Loyalitas (Y) memiliki nilai Cronbachs Alpha dan Composite Reliability lebih besar dari 0,7 dan semua variabel dinyatakan Reliabel (Ghozali, 2014).

\section{Hasil Uji Mediasi Penelitian}

Uji mediasi adalah seperangkat prosedur statistik yang digunakan untuk menyelidiki apakah kumpulan data tertentu menunjukan struktur mediasi (Dawn, 2008). Untuk mengetahui tingkat pengaruh di dalam jalur mediasinya menggunakan metode Variance Accounted For (VAF) yaitu untuk mengukur kriteria efek mediasi didasarkan pada nilai VAF. Apa bila nilai VAF $>80 \%$ maka Variabel mediasi bersifat Full Mediation, apa bila $20 \% \leq \mathrm{VAF} \leq 80 \%$ variabel mediasi bersifat partial mediation, dan apa bila VAF $<20 \%$ maka variabel Mediasi bukan bersifat mediasi (Hair, 2013).

1. Menentukan pengaruh langsung antara variabel Kualitas pelayanan (X1) dengan Loyalitas (Y). apa bila koefisien jalur sebesar > 0,70 dan signifikan 0,01 maka dapat dikatakan ada signifikansi pengaruh langsung (Solihin 2013), Hasil pengujian pengaruh langsung dapat dilihat di Tabel 4.28 sebagai berikut : 
Tabel 6 Hasil Uji Mediasi Pengaruh Langsung X1 dan Y

\begin{tabular}{cccc} 
Variabel & $\begin{array}{c}\text { Kualitas } \\
\text { Pelayanan }\end{array}$ & sig & Keterangan \\
\hline Loyalitas & 0,92 & $<0,01$ & $\begin{array}{l}\text { pengaruh } \\
\text { langsung } \\
\text { signifikan }\end{array}$ \\
\hline
\end{tabular}

Sumber: Data diolah, 2020

Dari Tabel di atas, Maka dapat dikatakan Bahwa antara Variabel X1 dan Y mempunyai Pengaruh langsung Signifikan, maka dapat dilakukan perhitungan Mediasi.

2. Menentukan pengaruh tidak langsung antara variabel Kualitas pelayanan (X1), Kepuasan Konsumen (Z) dan Loyalitas (Y). apa bila koefisien jalur sebesar $>0,70$ dan signifikan 0,01 maka dapat dikatakan pengaruh tidak langsung signifikan (Solihin 2013), Hasil pengujian pengaruh langsung dapat dilihat di Tabel 7 sebagai berikut:

Tabel 7 Hasil Uji Mediasi Pengaruh Tidak Langsung $\mathrm{X} 1, \mathrm{Z}$, dan Y

\begin{tabular}{ccccl}
\hline Variabel & $\begin{array}{c}\text { Kualitas } \\
\text { Pelayanan }\end{array}$ & Loyalitas & Sig & Keterangan \\
\hline $\begin{array}{l}\text { Kepuasan } \\
\text { Konsumen }\end{array}$ & 0,94 & 0,81 & $<0,01$ & $\begin{array}{l}\text { Pengaruh } \\
\text { tidak } \\
\text { langsung } \\
\text { signifikan }\end{array}$ \\
\hline Loyalitas & 0,16 & & $\begin{array}{l}\text { Pengaruh } \\
\text { langsung } \\
\text { tidak } \\
\text { signifikan }\end{array}$ \\
\hline
\end{tabular}

Sumber: Data diolah, 2020

Berdasarkan Tabel di atas, maka hasil uji mediasi untuk pengaruh tidak langsung signifikan dan pengaruh langsung nilai koefisien jalurnya mengecil dari 0,92 menjadi 0,16 , hal ini menunjukan bahwa Variabel Pemediasi mampu menyerap Pengaruh langsung dari model tanpa pemediasi. Maka dalam hal ini akan dilakukan perhitungan VAF untuk menentukan seberapa besar peran Pemediasi tersebut.

$$
\begin{aligned}
& \mathrm{VAF}=\frac{\text { pengaruh tidak langsung }}{\text { pengaruh total }} \times 100 \% \\
& \begin{aligned}
\mathrm{VAF} & =0,94 \times 0,81 / 0.94 \times 0,81+0,16 \\
& =0,83 \times 100 \% \\
\mathrm{VAF} & =83 \%
\end{aligned}
\end{aligned}
$$

Dari perhitungan diatas maka dapat disimpulkan bahwa terdapat efek mediasi penuh atau Mediation full, dalam hal ini menunjukan Bahwa variabel
Kepuasan Konsumen menjadi pemediasi penuh antara kualitas pelayanan dan Loyalitas.

3. Menentukan pengaruh langsung antara variabel Fasilitas (X2) dengan Loyalitas (Y)

Apa bila koefisien jalur sebesar $>0,70$ dan signifikan 0,01 maka dapat dikatakan ada signifikansi pengaruh langsung (Solihin 2013), Hasil pengujian pengaruh langsung dapat dilihat di Tabel sebagai berikut :

Tabel 8 Hasil Uji Mediasi Pengaruh Langsung X2 dan Y

\begin{tabular}{cccc}
\hline Variabel & Fasilitas & sig & Keterangan \\
\hline Fasilitas & 0,91 & $<0,01$ & $\begin{array}{l}\text { pengaruh langsung } \\
\text { signifikan }\end{array}$ \\
\hline
\end{tabular}

Sumber: Data diolah, 2020

Dari Tabel di atas, Maka dapat dikatakan Bahwa antara Variabel X2 dan Y mempunyai Pengaruh langsung Signifikan, maka dapat dilakukan perhitungan Mediasi.

4. Menentukan pengaruh tidak langsung antara variabel Fasilitas (X2) Kepuasan Konsumen (Z) dan Loyalitas (Y)

Apa bila koefisien jalur sebesar $>0,70$ dan signifikan 0,01 maka dapat dikatakan pengaruh tidak langsung signifikan (Solihin 2013), Hasil pengujian pengaruh langsung dapat dilihat di Tabel dibawah ini:

Tabel 9 Hasil Uji Mediasi Pengaruh Tidak Langsung $\mathrm{X} 2, \mathrm{Z}$, dan Y

\begin{tabular}{ccccl}
\hline Variabel & Fasilitas & Loyalitas & Sig & Keterangan \\
\hline $\begin{array}{c}\text { Kepuasan } \\
\text { Konsumen }\end{array}$ & 0,94 & 0,91 & $<0,01$ & $\begin{array}{l}\text { Pengaruh } \\
\text { tidak } \\
\text { langsung } \\
\text { signifikan }\end{array}$ \\
\hline Loyalitas & 0,05 & & 0,44 & $\begin{array}{l}\text { Pengaruh } \\
\text { langsung } \\
\text { tidak } \\
\text { signifikan }\end{array}$ \\
\hline
\end{tabular}

Sumber: Data diolah, 2020

Berdasarkan Tabel di atas, maka hasil uji mediasi untuk pengaruh tidak langsung signifikan dan pengaruh langsung nilai koefisien jalurnya mengecil dari 0,91 menjadi 0,05, hal ini menunjukan bahwa Variabel Pemediasi mampu menyerap Pengaruh langsung dari model tanpa pemediasi. Maka dalam hal ini akan dilakukan perhitungan VAF untuk menentukan seberapa besar peran Pemediasi tersebut. 


$$
\begin{gathered}
\mathrm{VAF}=\frac{\text { pengaruh tidak langsung }}{\text { pengaruh total }} \times 100 \% \\
\begin{array}{r}
\mathrm{VAF}=0,94 \times 0,91 / \begin{array}{c}
0.94 \times 0,91+0,05 \\
=0,94 \times 100 \% \\
\mathrm{VAF} \quad
\end{array} \\
=94 \%
\end{array}
\end{gathered}
$$$$
\rightarrow(2)
$$

Dari perhitungan diatas maka dapat disimpulkan bahwa terdapat efek mediasi penuh atau Mediation full, dalam hal ini menunjukan Bahwa variabel Kepuasan Konsumen menjadi pemediasi penuh antara Fasilitas dan Loyalitas.

\section{Hasil Uji Hipotesis}

Menurut Sugiono (2014) hipotesis merupakan jawaban sementara terhadap rumusan masalah penelitian. Kebenaran dari hipotesis harus dibuktikan dengan data yang terkumpul. Langkahlangkah untuk menetapkan hipotesis dimulai dengan menetapkan nilai Path Coefficients harus positif dan $P$-values harus dibawah 0,05 dan kemudian menentukan seberapa besar pengarunya dengan melihat nilai Rsquare. Adapun uji hipotesis dalam penelitian ini diambil sebanyak 53 Responden, dengan hasil yang akan diuraikan sebagai berikut:

\section{$\mathrm{H}_{1}$ : Kualitas pelayanan berpengaruh signifikan terhadap loyalitas pelanggan pada Café Hangout di Sampit}

Tabel 10 Hasil Uji hipotesis Variabel X1 Terhadap Y

\begin{tabular}{cccc}
\hline Variabel & $\begin{array}{c}\text { Path } \\
\text { Coefficients }\end{array}$ & P-Values & R-Square \\
\hline $\begin{array}{c}\text { (X1) } \\
\text { Terhadap } \\
\text { (Y) }\end{array}$ & 0,917 & $<0,001$ & 0,84 \\
\hline
\end{tabular}

Sumber: Data diolah, 2020

Dari Tabel di atas, menunjukan bahwa Kualitas pelayanan berpengaruh positif dan signifikan terhadap Loyalitas pada Café Hangout Dan mempunyai pengaruh sebesar $84 \%$.

\section{$\mathrm{H}_{2}$ : Fasilitas berpengaruh signifikan terhadap loyalitas konsumen pada Café Hangout di Sampit}

Tabel 11 Hasil Uji hipotesis Variabel X2 Terhadap Y

\begin{tabular}{cccc} 
Variabel & $\begin{array}{c}\text { Path } \\
\text { Coefficients }\end{array}$ & P-Values & R-Square \\
\hline $\begin{array}{c}\text { (X2) } \\
\text { (Y) }\end{array}$ & 0,906 & $<0,001$ & 0,82 \\
& & & \\
\hline
\end{tabular}

Sumber: Data diolah, 2020
Dari Tabel di atas, menunjukan bahwa Fasilitas berpengaruh positif dan signifikan terhadap Loyalitas pada Café Hangout Dan mempunyai pengaruh sebesar $82 \%$.

\section{$\mathbf{H}_{3}$ : Kualitas pelayanan berpengaruh signifikan terhadap kepuasan konsumen pada Café Hangout di Sampit}

Tabel 12 Hasil Uji hipotesis Variabel X1 Terhadap Z

\begin{tabular}{cccc}
\hline Variabel & $\begin{array}{c}\text { Path } \\
\text { Coefficients }\end{array}$ & $\begin{array}{c}\boldsymbol{P} \text { - } \\
\text { Values }\end{array}$ & $\begin{array}{c}\text { R- } \\
\text { Square }\end{array}$ \\
\hline $\begin{array}{c}\text { (X1) } \\
\text { Terhadap } \\
\text { (Z) }\end{array}$ & 0,941 & $<0,001$ & 0,89 \\
\hline Sumber: Data diolah, 2020 & & \\
\hline
\end{tabular}

Sumber: Data diolah, 2020

Dari Tabel di atas, menunjukan bahwa Kualitas pelayanan berpengaruh positif dan signifikan terhadap Kepuasan Konsumen pada Café Hangout Dan mempunyai pengaruh sebesar $89 \%$.

\section{$\mathrm{H}_{4}$ : Fasilitas berpengaruh signifikan terhadap kepuasan konsumen pada Café Hangout di Sampit}

Tabel 13 Hasil Uji hipotesis Variabel X2 Terhadap Z

\begin{tabular}{cccc} 
Variabel & $\begin{array}{c}\text { Path } \\
\text { Coefficients }\end{array}$ & $\begin{array}{c}\boldsymbol{P} \text { - } \\
\text { Values }\end{array}$ & R-Square \\
\hline $\begin{array}{c}\text { (X2) } \\
\text { Terhadap }\end{array}$ & 0,942 & $<0,001$ & 0,89 \\
\hline Z $)$ & & &
\end{tabular}

(Z)

Sumber: Data diolah, 2020

Dari Tabel di atas, menunjukan bahwa Fasilitas berpengaruh positif dan signifikan terhadap Kepuasan Konsumen pada Café Hangout Dan mempunyai pengaruh sebesar $89 \%$.

\section{$\mathrm{H}_{5}$ : Kepuasan Konsumen Berpengaruh Signifikan Terhadap Loyalitas Pada Café Hangout Di Sampit}

Tabel 14 Hasil Uji hipotesis Variabel Z Terhadap Y

\begin{tabular}{cccc}
\hline Variabel & Path Coefficients & P-Values & R-Square \\
\hline $\begin{array}{c}\text { (Z) } \\
\begin{array}{c}\text { Terhadap } \\
\text { (Y) }\end{array}\end{array}$ & 0,956 & $<0,001$ & 0,91 \\
\hline \multicolumn{2}{r}{ Sumber: Sumber: Data diolah, 2020} &
\end{tabular}

Dari Tabel di atas, menunjukan bahwa Kepuasan konsumen berpengaruh positif dan signifikan terhadap Loyalitas pada Café Hangout Dan mempunyai pengaruh sebesar $91 \%$. 


\section{HASIL DAN PEMBAHASAN}

1. Pengaruh kualitas pelayanan berpengaruh signifikan terhadap loyalitas pelanggan.

Pada pengujian hipotesis pertama membuktikan bahwa kualitas pelayanan berpengaruh signifikan terhadap loyalitas dengan nilai path coefificients sebesar 0,917 dengan $p$-values sebesar $<0,001$ lebih kecil dari 0,05 . Hasil ini sesuai dengan penelitian Indralutfi, Pradhanawati \& Susanta (2013) dengan hasil bahwa kualitas pelayanan berpengaruh signifikan terhadap loyalitas

2. Pengaruh fasilitas berpengaruh signifikan terhadap loyalitas pelanggan

Pada pengujian hipotesis kedua membuktikan bahwa fasilitas berpengaruh signifikan terhadap loyalitas dengan nilai path coefificients sebesar 0,906 dengan p-values sebesar <0,001 lebih kecil dari 0,05. Hasil ini sesuai dengan penelitian indralutfi, pradhanawati \& susanta (2013) dengan hasil bahwa fasilitas berpengaruh signifikan terhadap loyalitas

3. Pengaruh kualitas pelayanan berpengaruh signifikan terhadap kepuasan konsumen.

Pada pengujian hipotesis ketiga membuktikan bahwa kualitas pelayanan berpengaruh signifikan terhadap kepuasan konsumen dengan nilai path coefificients sebesar 0,941 dengan $p$-values sebesar $<0,001$ lebih kecil dari 0,05 . Hasil ini sesuai dengan penelitian Indralutfi, Pradhanawati \& Susanta (2013) dengan hasil bahwa kualitas pelayanan berpengaruh signifikan terhadap kepuasan konsumen

4. Pengaruh fasilitas berpengaruh signifikan terhadap kepuasan konsumen.

Pada pengujian hipotesis keempat membuktikan bahwa fasilitas berpengaruh signifikan terhadap kepuasan konsumen dengan nilai path coefificients sebesar 0,942 dengan $p$-values sebesar $<0,001$ lebih kecil dari 0,05 . Hasil ini sesuai dengan penelitian Indralutfi, Pradhanawati \& Susanta (2013) dengan hasil bahwa fasilitas berpengaruh signifikan terhadap kepuasan konsumen

5. pengaruh kepuasan konsumen berpengaruh signifikan terhadap loyalitas

Pada pengujian hipotesis kelima membuktikan bahwa kepuasan konsumen berpengaruh signifikan terhadap loyalitas dengan nilai path coefificients sebesar 0,956 dengan $p$-values sebesar <0,001 lebih kecil dari 0,05. Hasil ini sesuai dengan penelitian Indralutfi, Pradhanawati \& Susanta (2013) dengan hasil bahwa kepuasan konsumen berpengaruh signifikan terhadap loyalitas dengan hasil korelasi sebesar 0,662.

\section{SIMPULAN DAN SARAN}

\section{Simpulan}

Berdasarkan hasil penelitian mengenai Pengaruh kualitas Pelayanan Dan Fasilitas Terhadap Loyalitas di Café Hangout Melalui Kepuasan Konsumen Sebagai Variabel Intervening dapat di ambil kesimpulan bahwa berdasarkan pada uji mediasi menunjukan bahwa efek mediasi kepuasan konsumen dalam mempengaruhi kualitas pelayanan terhadapa loyalitas di Café Hangout Sampit mempunyai efek sebesar $83 \%$. Hal ini menunjukan variabel pemediasi mempunyai pengaruh penuh untuk memediasi variabel kualitas pelayan terhadap Loyalitas.

Berdasarkan pada uji mediasi menunjukan bahwa efek mediasi kepuasan konsumen dalam mempengaruhi fasilitas terhadap loyalitas di Café hangout Sampit mempunyai efek sebesar 94\%. Hal ini menunjukan variabel pemediasi mempunyai pengaruh penuh untuk memediasi variabel fasilitas terhadap loyalitas.

Berdasarkan uji hipotesis menunjukan bahwa kualitas pelayanan berpengaruh positif terhadap Loyalitas di Café Hangout Sampit dengan pengaruh 84\%. Hal ini dibuktikan dengan nilai Path Coefficients positif dan $P$-values harus dibawah 0,05 .

Berdasarkan uji hipotesis menunjukan bahwa Fasilitas berpengaruh positif terhadap Loyalitas di Café Hangout Sampit dengan pengaruh $82 \%$. Hal ini dibuktikan dengan nilai Path Coefficients positif dan $P$-values harus dibawah 0,05.

Berdasarkan uji hipotesis menunjukan bahwa kualitas pelayanan berpengaruh positif terhadap kepuasan konsumen di Café Hangout Sampit dengan pengaruh $89 \%$. Hal ini dibuktikan dengan nilai Path Coefficients positif dan P-values harus dibawah 0,05 .

Berdasarkan uji hipotesis menunjukan bahwa Fasilitas berpengaruh positif terhadap kepuasan konsumen di Café Hangout Sampit dengan pengaruh $89 \%$. Hal ini dibuktikan dengan nilai Path Coefficients positif dan $P$-values harus dibawah 0,05 .

Berdasarkan uji hipotesis menunjukan bahwa kepuasan konsumen berpengaruh positif terhadap 
Loyalitas di Café Hangout Sampit dengan pengaruh 91\%. Hal ini dibuktikan dengan nilai Path Coefficients positif dan $P$-values harus dibawah 0,05 .

\section{Saran}

Berdasarkan kesimpulan diatas, maka peneliti dapat memberikan saran bahwa pemenuhan Kualitas pelayanan hendaknya mengoptimalkan semua faktor yang dimiliki sehingga akan terjadi keseimbangan setiap faktor dalam dimensi kualitas pelayanan di Café Hangout. Berdasarkan temuan dalam penelitian ini, dimensi dari kualitas pelayanan mendapatkan penilaian rendah adalah karyawan kurang menerapkan SOP dalam melayani tamu, hal ini menunjukan bahwa pihak Café hangout harus memberikan pelatihan kepada setiap karyawannya. Sehingga konsumen akan merasa senang dilayani dengan baik dan mau kembali lagi dilain waktu ke café hangout.

Pemenuhan Fasilitas hendaknya mengoptimalkan semua faktor yang dimiliki sehingga akan terjadi keseimbangan setiap faktor dalam dimensi fasilitas di Café Hangout. Berdasarkan temuan dalam penelitian ini, dimensi dari kualitas pelayanan mendapatkan penilaian rendah adalah kurangnya tempat parkir mobil. Hal ini menunjukan pihak Café hangout harus memperluas lahan parkir untuk mobil, sehingga konsumen yang membawa mobil mendapatkan tempat parkir yang nyaman.

Pemenuhan Kepuasan Konsumen hendaknya mengoptimalkan semua faktor yang dimiliki sehingga akan terjadi keseimbangan setiap faktor dalam dimensi kepuasan konsumen di Café Hangout. Berdasarkan temuan dalam penelitian ini, dimensi dari kepuasan konsumen mendapatkan penilaian rendah adalah pemenuhan pesanan konsumen yang cendrung memakan waktu lama, hal ini menunjukan bahwa pihak café hangout harus memperbaiki pesanan dengan waktu cepat. Sehingga konsumen tidak menunggu lama untuk pesanan yang mereka pesan.

Pemenuhan Loyalitas hendaknya mengoptimalkan semua faktor yang dimiliki sehingga akan terjadi keseimbangan setiap faktor dalam dimensi Loyalitas di Café Hangout. Berdasarkan temuan dalam penelitian ini, dimensi dari loyalitas mendapatkan penilaian rendah adalah Café hangout tidak dapat mempertahankan pelanggannya dari produk sejenis dari pesaing. Hal ini menunjukan bahwa pihak café hangout harus melakukan perbaikan kualitas pelayanan dan kualitas produknya agar konsumen tetap bertahan di café hangout.

\section{DAFTAR PUSTAKA}

Ali Hasan. 2014. Marketing dan Kasus-Kasus Pilihan. CAPS. Yogyakarta

Cohen,J. 1992. “A Power Primer”. Psychological Bulletin, 112: 155-159

Fandy, Tjiptono dan Greforius, Chandra. 2016. Pemasaran Jasa (Prinsip, Penerapan, dan Penelitian). CV. Andi Offset. Yogyakarta

Ghozali, Imam. 2009. Aplikasi Analisis Multivariate Dengan Program SPSS. Semarang: BP UNDIP.

Ghozali. 2013. Aplikasi Analisis Multivariate dengan Program SPSS Cetakan VI. Badan Penerbit Universitas Diponegoro. Semarang.

Ghozali, Imam. 2014. Structural Equation Modelling, Edisi II, Universitas Diponegoro, Semarang

Gomes, Faustino Cardoso. 2010, Manajemen Sumber Daya Manusia, Jakarta : Indeks.

Handoko, T. Hani. 2008. Manajemen Personalia dan Sumber Daya Manusia. BPFE. YogyakartaHariandja, Effendi. 2005. Manajemen Sumber Daya Manusia. Bandung: Universitas Parayangan.

Hariandja, Effendi. 2002. Manajemen Sumber Daya Manusia. Bandung: Universitas Parayangan.

Husein Umar. 2005. Riset Pemasaran dan Perilaku Konsumen. Jakarta : PT Gramedia Pustaka Utama.

Jillian C. Sweeney dan Geoffrey N. Soutar. 2001. "Consumer perceived value: The development of a multiple item scale. Journal of Retailing 77 203-220.

Hair et. Al. 2013. A primer on Partial Least Squares Structural EquationModeling (PLS-SEM

Indra Lutfi Sofyan, Ari Pradhanawati \& Hari Susanta Nugraha. 2013. Pengaruh Fasilitas dan Kualitas Pelayanan Terhadap Loyalitas, Melalui Kepuasan Konsumen Sebagai Variabel Intervening pada Star Clean Car Wash Semarang. Volume 2, Nomor 2. Diponegoro

Kotler, Keller. 2016. Marketing Management. 15e, Boston, Pearson Education

Kotler, Philip. 2012. Manajemen Pemasaran di Indonesia: Analisis, Perencanaan, Implementasi dan Pengendalian. Salemba Empat. Jakarta 
Mahfud Sholihin, dan Dwi Ratmono, 2013. Analisis SEM-PLS Dengan WarpPLS 3.0 Untuk Hubungan Nonlinier Dalam Penelitian Sosial Dan Bisnis. CV. Andi Offset. Yogyakarta

Sholihin, Mahfud, Ph.D dan Ratmono Dwi, Dr (2013) “Analisis SEM-PLS dengan Wrap PLS 3.0 untuk Hubungan Nonlinier dalam Penelitian Sosial dan Bisnis". CV.Andi Offset. Yogyakarta

Sugiyono. 2012. Metode Penelitian Kuantitatif Kualitatif dan $R \& D$. Alfabeta. Bandung

Tjiptono, Fandy. 2000. Manajemen Jasa. Yogyakarta: Andi Yogyakarta. 